\title{
Sampling method for surveying complex and multi-institutional partnerships: lessons from the Global Polio Eradication Initiative
}

\author{
Michael A. Peters ${ }^{1 *}$, Wakgari Deressa ${ }^{2}$, Malabika Sarker $^{3}$, Neeraj Sharma ${ }^{4}$, Eme Owoaje ${ }^{5}$, Riris Andono Ahmad ${ }^{6}$, \\ Tawab Saljuqii ${ }^{7}$ Eric Mafuta ${ }^{8}$ and Olakunle Alonge ${ }^{1}$
}

\begin{abstract}
Background: Complex global initiatives, like the Global Polio Eradication Initiative (GPEl), have prevented millions of paralyses and improved the health status of diverse populations. Despite the logistical challenges these initiatives must overcome at several levels, scant methods exist for systematically identifying and reaching a range of actors involved in their implementation. As a result, efforts to document the lessons learned from such initiatives are often incomplete. This paper describes the development and application of the Synthesis and Translation of Research and Innovations from Polio Eradication (STRIPE) systematic approach for identifying a comprehensive sample of actors involved in the GPEl.
\end{abstract}

Results: The survey for collecting lessons learned from the GPEI was conducted at the global level and within seven countries that represented GPEl operational contexts. Standard organizational and operational levels, as well as goals of program activities, were defined across contexts. Each survey iteration followed similar methodologies to theorize a target population or "universe" of all polio-related actors in the study area, enumerate a source population of specific individuals within the target population, and administer the survey to individuals within the source population. Based on the systematic approach used to obtain a comprehensive sample for lessons learned in GPEl, steps for obtaining a comprehensive sample for studying complex initiatives can be summarized as follows: (i) State research goal(s); (ii) Describe the program of interest; (iii) Define a sampling universe to meet these criteria; (iv) Estimate the size of the sampling universe; (v) Enumerate a source population within the universe that can be feasibly reached for sampling; (vi) Sample from the source population; and (vii) Reflect on the process to determine strength of inferences drawn.

Conclusions: The application of these methods can inform future evaluations of complex public health initiatives, resulting in better adoption of lessons learned, ultimately improving efficacy and efficiency, and resulting in significant health gains. Their use to administer the STRIPE lessons learned survey reflects experiences related to implementation challenges and strategies used to overcome barriers from actors across an extensive range of organizational, programming, and contextual settings.

Keywords: Complex initiative, Evaluation, GPEl, Lessons learned, Polio, Sampling

\footnotetext{
* Correspondence: mpeters@jhu.edu

'Johns Hopkins University Bloomberg School of Public Health, Baltimore, MD,

USA

Full list of author information is available at the end of the article
}

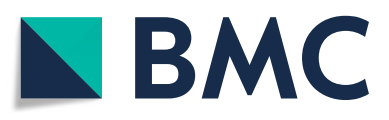

(0) The Author(s). 2020 Open Access This article is licensed under a Creative Commons Attribution 4.0 International License, which permits use, sharing, adaptation, distribution and reproduction in any medium or format, as long as you give appropriate credit to the original author(s) and the source, provide a link to the Creative Commons licence, and indicate if changes were made. The images or other third party material in this article are included in the article's Creative Commons licence, unless indicated otherwise in a credit line to the material. If material is not included in the article's Creative Commons licence and your intended use is not permitted by statutory regulation or exceeds the permitted use, you will need to obtain permission directly from the copyright holder. To view a copy of this licence, visit http://creativecommons.org/licenses/by/4.0/. The Creative Commons Public Domain Dedication waiver (http://creativecommons.org/publicdomain/zero/1.0/) applies to the data made available in this article, unless otherwise stated in a credit line to the data. 


\section{Background}

The global health landscape contains a multitude of complex initiatives, defined as those having "multiple activity components; varied settings for implementation of different sets of activities; systems-strengthening efforts; capacity building; efforts to influence policy changes; use of health diplomacy to achieve the aims of the initiative; and implementation at multiple levels through a large number of diverse, multisectoral partners at the country level" [1]. Some examples include vertical and diseasefocused initiatives [e.g. Global Fund to Fight AIDS, Tuberculosis and Malaria; Global Polio Eradication Initiative (GPEI); US President's Emergency Plan for AIDS Relief (PEPFAR); President's Malaria Initiative (PMI)]; programs that focus on a certain aspect of health services delivery (e.g. vaccine support provided by Gavi, the Vaccine Alliance); and broader health systems strengthening (e.g. research grants provided by the Alliance for Health Policy and Systems Research).

Although much attention has been paid to the evaluation of these complex initiatives, few methods exist to systematically identify and select comprehensive samples of populations involved in their implementation [1, 2]. Such methods would facilitate the identification of lessons that may be applicable for improving efficacy within the initiative, in addition to generating lessons that can be applied to other programs. It is essential that evaluations are done to describe these lessons about the processes, implementation strategies, and experiences of individuals at various operational levels and across contexts within these initiatives, and that methods are developed to ensure that these lessons can be generalized and appropriately incorporated in future efforts [3]. While many studies seek to distill these lessons, few adopt a systematic approach to ensure that perspectives across the spectrum of involved actors are captured, instead relying primarily on the experiences of leadership and a few key actors. Without a systematic approach, the valuable tacit knowledge of those involved with program implementation may not be captured, in which case lessons learned will not realize their full potential to improve future efforts.

In the epidemiological tradition, a key principle in generalizing findings of a study to a larger group is to define

Table 1 Definitions of population groups

\footnotetext{
The definition of target, source, and study populations are interrelated and are a starting point for the methods described in this paper. These concepts are defined as follows [4];

- Target Population: The collection of individuals, items, measurements, etc., about which inferences are desired. The term is sometimes used to indicate the population or group from which a sample or study population is drawn and sometimes to denote a reference population about which inferences are desired

- Source Population: The group from which a study group is selected - Study Population: The group selected for investigation.
}

a target, a source, and a study population (See Table 1). Aspects of this principle can be extended to describe overall experiences and lessons learned within the population of actors involved in a complex initiative. However, unlike populations in epidemiology, which are often defined by characteristics through which individuals can be readily recruited into a study (e.g. gender, age, exposure to specific risk factors), populations of actors involved in a complex and multi-institutional initiative may be hard to identify (that is, hard-to-reach) due to lack of an easily identified characteristic that is shared by all those necessary to make an initiative successful. For example, the GPEI - which has prevented millions of paralyses from the poliovirus and improved the health status of diverse populations [5] - is a partnership comprised of national governments and five ${ }^{1}$ international organizations, thus there is no designation such as being a GPEI "staff-member" which would identify membership in polio eradication at global or national levels. Furthermore, challenges like language diversity, documentation problems, lack of internet connectivity, and time since involvement in polio activities present additional barriers to collecting information from all those involved in polio eradication.

Social sciences approaches used for generalizing findings of a study rely on sampling from a universe of population groups identified by fairly overt and homogenous characteristics, similar to the epidemiological traditions (see Table 1). The universe "consists of all survey elements that qualify for inclusion in the research study, and the precise definition of the universe for a particular study is set by the research question, which specifies who or what is of interest" [6]. Roughly analogous to the target population in epidemiology, the question-based nature of a 'universe' allows for more flexibility in defining who can exist within the qualifying population. A discussion of sampling within the field of organizational research studies noted the reluctance of authors to explicitly state the universe, or target population to which their findings are generalizable [7]. Other methods have been developed to obtain sampling frames (source populations) for organizational research, but these methods rely on the presence of a variety of well-maintained centralized lists, such as unemployment insurance databases that do not exist in the context of polio eradication [8].

Approaches have also been developed for sampling hidden populations in public health initiatives, such as men who have sex with men [9], drug users [10], and undocumented immigrants [11], and aspects of these approaches

\footnotetext{
${ }^{1}$ In March 2019, a sixth partner, Gavi the Vaccine Alliance, has joined the GPEI core partnership. Since Gavi was not a core partner during protocol development and data collection, this paper does not include the organization as a core member
} 
can be adapted for complex global health initiatives involving multiple actors. Although these techniques yield valuable lessons, when target and source populations are not well described and identified, as seen with complex global health initiatives like the GPEI, findings can be based on samples that lack representativeness, and may miss important lessons learned at various levels of operation. Other methods have been developed to study complex interventions and systems, including system dynamic modelling, agent-based modelling, network analysis, and systems mapping [12]. These methods are useful in understanding how interventions and systems interact with each other, describing how individuals/agents behave within complex systems, and/or hypothesizing and modeling intervention impacts. Although expanding in applicability, these methods are still under-developed in their current form to guide sampling from complex systems which have a wide breadth of actors working at various levels. A review of selected studies of complex initiatives conducted between 2007 and 2011 demonstrates the lack of attempts to quantitatively describe target and source populations (Table 2).

Indeed, there is a gap in methods for defining and implementing a sampling process for participants of a large, complex initiative that could span multiple countries and organizations that exists both in broader biomedical and social sciences $[1,7,8,12]$. The goal of this paper is to describe a sampling approach for surveying complex and multi-institutional partnerships, and to identify a study population for evaluating a complex program than spans multiple countries and organizations based on a knowledge translation project around the GPEI and polio eradication activities.

\section{Synthesis and translation of research and innovations from polio eradication}

The Synthesis and Translation of Research and Innovations from Polio Eradication (STRIPE) project seeks to map, package and disseminate knowledge gained from the GPEI and polio eradication activities and is described elsewhere [18]. To that end, the project conducted a "tacit knowledge survey" to capture ideas, approaches and experiences that are not documented, but relevant to understanding both intended and unintended results from polio eradication activities. In order to ensure that findings from the tacit knowledge survey represent the full spectrum of actors involved in polio eradication activities, a systematic approach was developed to define

Table 2 Review of descriptions of target, source, and study populations in previous studies of complex initiatives

\begin{tabular}{|c|c|c|}
\hline Initiative/ Study & Objective of Study & Target Population \\
\hline $\begin{array}{l}\text { External Evaluation Of } \\
\text { The President's Malaria } \\
\text { Initiative (PMI) [13] }\end{array}$ & $\begin{array}{l}\text { Review the first five years } \\
\text { (FY06-FY10) of PMI's activities, } \\
\text { organized around six core } \\
\text { objectives }\end{array}$ & Not described \\
\hline $\begin{array}{l}\text { Five Year Evaluation of } \\
\text { the Global Fund: Study } \\
\text { Area 1; Organizational } \\
\text { Development study } \\
\text { [14] }\end{array}$ & $\begin{array}{l}\text { Assess organizational efficiency } \\
\text { and effectiveness of the Global } \\
\text { Fund, }\end{array}$ & $\begin{array}{l}\text { Described staff in terms } \\
\text { of unit ( } 7 \text { types) and } \\
\text { level ( } 3 \text {; senior } \\
\text { managers, managers, } \\
\text { and other staff). } \\
\text { Total staff estimates } \\
\text { were not quantitatively } \\
\text { described }\end{array}$ \\
\hline
\end{tabular}

Five Year Evaluation of Assess effectiveness of the the Global Fund: Study Global Fund partnership Area 2 [15] environment

Evaluation of the

Assess PEPFAR's performance Plan for AIDS Relief (PEPFAR) [16]

Second Gavi Evaluation [17] and its effects on health

\section{Not described}

(1)

Source Population
Focus on key actors, both interna
and external to PMI.
Not quantitatively described
$5 / 15$ focus countries visited
283 Secretariat staff at the time of
evaluation

Partners and stakeholders at the
country and global levels; grant
recipients and implementing
partners at the country level; fund
portfolio managers at the
Secretariat; technical assistance
partners at the country and glob
levels; civil society representatives.
16 focus countries
Individual source population not
described
31 focus countries, 13 of which
were visited
Online survey sent to 1,000
stakeholders
Imanager survey sent to 76
Immunization managers

Study Population

65 respondents with described position/role

89 Secretariat staff were involved (33 in preassessment meetings that identified 56 additional respondents)

Over 900 individuals interviewed

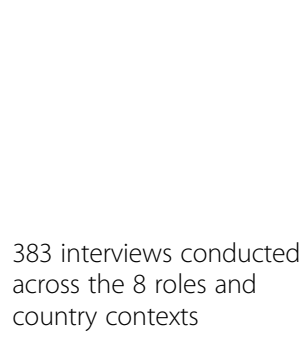
country contexts

Described interviews conducted in terms of 8 roles across countries Total staff estimates were not quantitatively described

Stakeholders of Gavi; 4 internal roles and 7 external roles described. Total stakeholder estimates were not quantitatively described
Assess the extent to which Gavi met its four strategic goals and the extent to which it has country levels
282 responses received, including half from partner institutions 23 responses received 109 consultations with roles described 
the total possible population of actors, list specific individuals that fit within the total population, and then derive a comprehensive sample of actors involved in global polio eradication activities at various levels. This paper describes the development and application of this approach for identifying a population of actors involved in the GPEI, and methods for conducting a tacit knowledge survey assessing lessons learned from the initiative. It is hoped that the steps distilled from completion of this activity will facilitate studies on other complex global health initiatives, and advance efforts to generalize and replicate findings from these studies in future.

\section{Results}

\section{Defining levels of representation}

The implementation of a complex initiative generally has many phases, including identifying stakeholders; designing a program; mobilizing resources; work planning; implementing; and monitoring, reviewing, and evaluating implementation [19]. For polio eradication, a wide range of stakeholders, including governments, country partners, and the five partner organizations of the GPEI (Rotary International, the World Health Organization (WHO), United Nations International Children's Fund (UNICEF), Centers for Disease Control and Prevention (CDC), and the Bill and Melinda Gates Foundation (BMGF)) participate in various phases of program implementation across numerous operational and organizational levels. The GPEI has operated in over 100 countries since inception in 1988, partnering with various levels of government (including host countries, bilateral/sovereign donor countries, and implementing countries) and with non-government organizations (NGOs) and civil society organizations (CSOs) as dictated by the local context. To derive a comprehensive sample of actors involved in GPEI and other polio eradication activities, information should be collected to reflect at a minimum (i) context typologies for polio implementation; (ii) implementation phases of polio eradication initiatives; and (iii) the pre-identified activities included in these phases.

Since it was not feasible to systematically collect lessons learned from every context where GPEI has operated, seven countries were purposively selected to represent a range of epidemiologic and operational contexts: Afghanistan, Bangladesh, Democratic Republic of Congo (DRC), Ethiopia, India, Indonesia, and Nigeria. The context typologies for polio implementation were defined based on the epidemiological, geographical, income, conflict, and other status ${ }^{2}$ [18]. Relevant organizations were broadly defined to include those involved with funding, researching, designing, managing, and implementing activities that contribute to polio eradication. In certain cases, this process was aided by referring to a country-specific "Polio Program Summary" which described the landscape of polio eradication in a country. After identifying these organizations and levels, common operational goals were identified through reviews of GPEI strategic plans through the lens of implementation frameworks [20, 21]. This information was collated in an operating list of contexts, organizational levels, and operational goals which was the starting point for describing the universe of individuals potentially involved in GPEI and polio eradication activities (Table 3).

\section{Theorizing a target population: the polio universe}

A universe is a tool for understanding all units that may be involved in a study, and in the STRIPE context refers to all potential individuals that qualify for inclusion in the tacit knowledge survey [6]. In addition to determining the individuals eligible for the study, defining the polio universe is also an essential step for understanding the population to which the results of the study will be applicable. The polio universe across the study areas was considered to be "the population of individuals who have been directly involved in implementing polio eradication related activities for 12 or more continuous months between 1988 till date." Implementing activities refer to all cycles of implementation, including GPEI-related funding, policy, programming, and research cycles. Researchers in the seven partner countries modified the parameters surrounding this definition to best represent the realities of polio eradication activities in their own setting as described below (Table 4).

While the core aspect of the polio universe definition did not change, i.e. you have to have worked for a continuous 12 months, country teams restricted the period considered to better match the reality of polio operations within their country. For example, Indonesia's last polio case was in 2006 and the polio-free certification was given in 2014, thus the country team prioritized data collection between 2000-2015 to match the period that polio activities became established in their country. Adapting the time frame of the polio universe is necessary for all countries to ensure that data was collected from the most relevant actors in a specific context. All

\footnotetext{
${ }^{2}$ In addition to polio status classification, the focus countries were selected based on the diversity and intensity of GPEI activities, informed by the extent of GPEI resources invested in that country over the last two decades. Under the assumption that knowledge assets around polio eradication will be concentrated where resources have been heavily targeted. The focus countries were further selected to represent different geographical regions where polio eradication activities have ramped up in recent times, country income classifications, conflict-affected compared to stable countries, and countries that could serve as influential regional leaders to facilitate uptake of knowledge by other countries in their region (STRIPE protocol paper)
} 
Table 3 Levels of representation within polio eradication

\begin{tabular}{|c|c|c|}
\hline $\begin{array}{l}\text { Country Polio Epidemiologic Contexts as of } 2018 \text { (and STRIPE focus } \\
\text { countries) }\end{array}$ & Examples of Organizational and Operational Levels & Polio Goals \\
\hline $\begin{array}{l}\text { Polio Endemic: } \\
\text { - Afghanistan } \\
\text { - Nigeria } \\
\text { Outbreak: } \\
\text { • DRC } \\
\text { High risk: } \\
\text { - Ethiopia }{ }^{a} \\
\text { Polio free: } \\
\text { - Bangladesh } \\
\text { - India } \\
\text { - Indonesia }\end{array}$ & $\begin{array}{l}\text { - Core GPEI members } \\
\text { o BMGF, CDC, Rotary, UNICEF, WHO } \\
\text { o Regional polio surveillance laboratories } \\
\text { - Country government officials } \\
\text { o State, District, and local level government } \\
\text { o Subnational monitoring boards } \\
\text { ○ Vaccinators } \\
\text { - Civil Sociey Organizations } \\
\text { ○ International Non-Government Organizations } \\
\text { ○ Local Non-Government Organizations } \\
\text { ○ Community organizers } \\
\text { o Local and religious leaders } \\
\text { - Other donor organizations and development } \\
\text { partners } \\
\text { o International development partners (USAID, } \\
\text { DFID, etc) } \\
\text { ○ Local donors/development partners }\end{array}$ & $\begin{array}{l}\text { - Resource mobilization } \\
\text { - Partnership/alliance } \\
\text { development } \\
\text { - Strategy development } \\
\text { and planning } \\
\text { - Strengthening delivery } \\
\text { services } \\
\text { - Vaccination } \\
\text { - Surveillance } \\
\text { - Community Engagement } \\
\text { - Monitoring and } \\
\text { Evaluation }\end{array}$ \\
\hline
\end{tabular}

"Ethiopia was "high risk" and Indonesia was "polio free" as designated by GPEI at the time of STRIPE protocol preparation. Both countries have since reported cases of circulating vaccine-derived poliovirus and are classified as "outbreak" countries as of 27 October 2019

country teams identified the organizational levels within a country and then estimated their polio eradicationspecific workforces over the relevant period of time. Afghanistan and DRC were two countries where additional information based on the structure of their health systems was combined with the organizational levels for polio program to describe a polio universe.

In Afghanistan, where NGOs play a large role in the health system, the polio universe was defined in terms of both state and non-state actors. Thus, the Afghanistan polio universe was systematically described along the six WHO health systems building blocks (service delivery, human resources, medical supplies, governance, health information, and finance) and stratified by government and non-government actors for each building block [22]. This framework-based approach helps to systematically describe the types of actors in an otherwise fragmented health system. In contrast, in the DRC, polio eradication closely follows the national health system, as it is integrated within the Expanded Program on Immunization (EPI) activities. Members of the polio universe were classified accordingly, including actors involved in immunization at the various health system levels, financing, technical, and implementing partners operational in the DRC. From this more concretely derived polio universe, it was then possible to utilize probability-based sampling methods.

\section{Enumerating the source population}

While describing the polio universe is necessary to understand all potential individuals who are eligible for responding to the study, it is not possible to implement data collection based on inclusion in the polio universe alone. The source population refers to all those who belong in the polio universe and can be reached for a tacit knowledge survey. Strategies for identifying specific individuals within a polio universe were shared and adapted across country teams to form a country-specific source population. One strategy involved identifying key government agencies, NGOs, religious organizations, civil society organizations, and academic communities involved in GPEI activities in the country in question through a variety of sources. Another strategy involved contacting point persons at identified key organizations and requesting lists of contact information for people and organizations who may belong to the polio universe across various countries. Once polio universes were defined and described, country partners used different criteria and assumptions for estimating the sample size taking into consideration the operational feasibility of the sample.

Most countries identified universes that contained more than 100,000 individuals and were forced to focus data collection efforts on key populations to achieve subnational representation of the polio universe. The most common method used was the selection of subnational geographic units for increased sampling. India's efforts to narrow down the largest estimated universe began with a stakeholder consultation workshop and resulted in the generation of a sampling frame of 4,792 individual respondents, complete with contact information. Review of the actors on this list determined that while state and national level actors from a range of organizations were included, frontline workers, such as Accredited Social Health Activists and Auxiliary Nurse Midwives were not represented because access to the internet was limited or their contact information was not available. Thus, a plan was made to perform snowball sampling to find frontline workers in four high-risk States in India. 
Table 4 Polio universe, source population, and study populations

\begin{tabular}{|c|c|c|c|c|c|c|}
\hline Country & Polio Universe Description & $\begin{array}{l}\text { Estimated } \\
\text { Universe Size } \\
\text { (Target } \\
\text { Population) }\end{array}$ & Operationalizing the Polio Universe & $\begin{array}{l}\text { Proposed } \\
\text { Sample } \\
\text { (Source } \\
\text { population) }\end{array}$ & Contact Plan & $\begin{array}{l}\text { Study } \\
\text { population }\end{array}$ \\
\hline Afghanistan & $\begin{array}{l}\text { Individuals with knowledge and } \\
\text { expertise of polio programs in the } \\
\text { country from directly working in the } \\
\text { polio eradication program. This } \\
\text { included anyone who has worked } \\
\text { directly in any level for policy } \\
\text { formulation, policy implementation, } \\
\text { program management, and field } \\
\text { operation. To have an inclusive } \\
\text { sample, Afghanistan's Polio Universe } \\
\text { was based on two frameworks; } \\
\text { WHO health system building blocks } \\
\text { and Afghanistan National Polio } \\
\text { Eradication Initiative. }\end{array}$ & 185,041 & $\begin{array}{l}\text { All national actors interviewed } \\
\text { with online survey ( } 206 \text { identified) } \\
\text { All provincial EPI teams contacted } \\
\text { with mobile phone survey ( } 442 \\
\text { identified) } \\
\text { Purposively selected } 7 \text { provinces } \\
\text { for in-person interviews }\end{array}$ & 65,041 & $\begin{array}{l}\text { Online survey } \\
\text { (31 } \\
\text { respondents, } \\
15.0 \% \\
\text { response rate) } \\
\text { Mobile Phone } \\
\text { survey (126 } \\
\text { respondents, } \\
28.5 \% \\
\text { response rate) } \\
\text { In-person } \\
\text { interviews } \\
\text { (365 } \\
\text { respondents) }\end{array}$ & 522 \\
\hline Bangladesh & $\begin{array}{l}\text { Individuals who spent } 12 \text { or more } \\
\text { continuous months working directly } \\
\text { in implementing activities under the } \\
\text { polio eradication program of } \\
\text { Bangladesh between } 1988 \text { till date. }\end{array}$ & 51,500 & $\begin{array}{l}\text { Snowball sampling to identify } \\
\text { respondents due to lack of } \\
\text { program intensity }\end{array}$ & 140 & $\begin{array}{l}\text { Online survey } \\
\text { ( } 23 \\
\text { respondents) } \\
\text { In-person } \\
\text { interviews ( } 83 \\
\text { respondents) }\end{array}$ & 106 \\
\hline DRC & $\begin{array}{l}\text { Since Polio was integrated within } \\
\text { the EPI Activities at the operational } \\
\text { level, the Polio universe comprised } \\
\text { all those dealing with it at different } \\
\text { levels of the health pyramid, } \\
\text { including external technical partners } \\
\text { (such as WHO, UNICEF, Sabin } \\
\text { Institute) and funding agencies } \\
\text { (such as the World Bank, the BMGF, } \\
\text { Rotary International, etc.) }\end{array}$ & 300,000 & $\begin{array}{l}\text { Stratified health districts based on } \\
\text { immunization coverage (good vs } \\
\text { bad), history of polio epidemics, } \\
\text { presence of AFP cases, and history } \\
\text { of cVDPV outbreaks and randomly } \\
\text { sampled districts by context type } \\
\text { Randomly sampled health areas } \\
\text { within each district and then } \\
\text { interviewed individuals within the } \\
\text { health areas. }\end{array}$ & 85,000 & $\begin{array}{l}\text { Online survey } \\
\text { (136 } \\
\text { respondents, } \\
34.75 \% \\
\text { response rate) } \\
\text { In-person } \\
\text { interviews } \\
\text { (400 } \\
\text { respondents) }\end{array}$ & 536 \\
\hline Ethiopia & $\begin{array}{l}\text { The polio universe in Ethiopia } \\
\text { included all individuals and partners } \\
\text { who have been involved for } 12 \text { or } \\
\text { more continuous months in } \\
\text { implementing polio eradication } \\
\text { activities in the country at national } \\
\text { and/or sub-national levels (Region, } \\
\text { Zone, District and health facilities); } \\
\text { in public and/or private sector; and } \\
\text { for NGOs between } 1996 \text { and } 2018 . \\
\text { It included individuals working at } \\
\text { the national level (FMoH, national } \\
\text { agencies such as EPHI and PSA, GPEl } \\
\text { partners, NGOs, Professional Associa- } \\
\text { tions), Universities and Research In- } \\
\text { stitutes, Regional Health Offices, } \\
\text { Zonal and District Health Offices, } \\
\text { Hospitals, health centers, health } \\
\text { posts, public and private health fa- } \\
\text { cilities, religious and clan leaders, } \\
\text { and communities and volunteers. }\end{array}$ & $\begin{array}{l}100,000 \text { health } \\
\text { workers who } \\
\text { could have been } \\
\text { involved in polio } \\
\text { eradication }\end{array}$ & $\begin{array}{l}\text { Purposively selected } 5 \text { regions } \\
\text { (Addis Ababa, Benishangul-Gumuz, } \\
\text { Gambella, Oromia, and Somali) }\end{array}$ & 150 & $\begin{array}{l}\text { Online survey } \\
(2 \\
\text { respondents, } \\
6.8 \% \text { response } \\
\text { rate) } \\
\text { In-person } \\
\text { interviews } \\
\text { (106 } \\
\text { respondents) }\end{array}$ & 108 \\
\hline India & $\begin{array}{l}\text { The polio universe consisted of } \\
\text { persons from Global Polio } \\
\text { Eradication Initiative (GPEI) partner } \\
\text { organizations, permanent and } \\
\text { contractual employees of central } \\
\text { and state government, members of } \\
\text { national and international NGOs, } \\
\text { teaching and non-teaching staffs of } \\
\text { schools, medical and non-medical }\end{array}$ & $\begin{array}{l}\text { Estimated over } \\
2.4 \text { million people } \\
\text { were involved in } \\
\text { polio eradication }\end{array}$ & $\begin{array}{l}\text { Stakeholder consultation workshop } \\
\text { with high level actors enabled a } \\
\text { list of } 4,957 \text { contacts }\end{array}$ & 4,957 & $\begin{array}{l}\text { Online survey } \\
\text { ( } 352 \\
\text { respondents } \\
7.1 \% \text { response } \\
\text { rate) } \\
\text { In-person } \\
\text { interviews } \\
\text { (165 } \\
\text { respondents) }\end{array}$ & 517 \\
\hline
\end{tabular}


Table 4 Polio universe, source population, and study populations (Continued)

\begin{tabular}{|c|c|c|c|c|c|c|}
\hline Country & Polio Universe Description & $\begin{array}{l}\text { Estimated } \\
\text { Universe Size } \\
\text { (Target } \\
\text { Population) }\end{array}$ & Operationalizing the Polio Universe & $\begin{array}{l}\text { Proposed } \\
\text { Sample } \\
\text { (Source } \\
\text { population) }\end{array}$ & Contact Plan & $\begin{array}{l}\text { Study } \\
\text { population }\end{array}$ \\
\hline & $\begin{array}{l}\text { volunteers. In addition, influencers } \\
\text { from religious institutions like tem- } \\
\text { ples, mosques, church etc. }\end{array}$ & & & & & \\
\hline Indonesia & $\begin{array}{l}\text { Actors who have spent } 12 \text { or more } \\
\text { continuous months directly and } \\
\text { indirectly for polio activities at } \\
\text { national and sub-national level } \\
\text { (provinces and districts) and re- } \\
\text { stricted to time period between } \\
\text { 1995-2014 (polio free certification) }\end{array}$ & 103,252 & $\begin{array}{l}\text { Purposively selected six provinces } \\
\text { (Aceh, Banten, West Java, DI } \\
\text { Yogyakarta, East Java, East Nusa } \\
\text { Tengarra) }\end{array}$ & 32,502 & $\begin{array}{l}\text { Online survey } \\
\text { In-person } \\
\text { interviews }\end{array}$ & 322 \\
\hline Nigeria & $\begin{array}{l}\text { A census of all actors who were } \\
\text { involved in GPEl activities in Nigeria, } \\
\text { from high level planners to project } \\
\text { managers and field immunizers on } \\
\text { a long-term basis ( } 12 \text { or more con- } \\
\text { tinuous months) within well-defined } \\
\text { periods between } 1988 \text { and } 2018 \text {. } \\
\text { Partners that were involved in the } \\
\text { survey include CDC, Rotary, WHO, } \\
\text { UNICEF, NSTOP, NEOC, NPHCDA, } \\
\text { Federal Ministry of Health, State } \\
\text { Ministry of Health and Local Gov- } \\
\text { ernment Area level. }\end{array}$ & 14,064 & $\begin{array}{l}\text { Purposively selected } 10 \text { states } \\
\text { (Anambra, Bayelsa, Borno, FCT, } \\
\text { Kano, Lagos, Nassarawa, Ondo, } \\
\text { Oyo and Sokoto). } \\
\text { Randomly selected } 4 \text { Local } \\
\text { Government Areas from each state }\end{array}$ & 3,906 & $\begin{array}{l}\text { Online survey } \\
\text { (793 } \\
\text { respondents) } \\
\text { In-person } \\
\text { interviews } \\
\text { (160 } \\
\text { respondents) }\end{array}$ & 953 \\
\hline $\begin{array}{l}\text { Global } \\
\text { Survey }\end{array}$ & $\begin{array}{l}\text { A population of individuals who } \\
\text { have been directly involved in } \\
\text { implementing activities under the } \\
\text { GPEl between } 1988 \text { till date. } \\
\text { Implementing activities refers to all } \\
\text { cycles of implementation, including } \\
\text { GPEl-related funding, policy, pro- } \\
\text { gramming, and research cycles. The } \\
\text { population includes individuals who } \\
\text { have spent } 12 \text { or more continuous } \\
\text { months working on activities under } \\
\text { the GPEI between } 1988 \text { till date. }\end{array}$ & $\begin{array}{l}3,929 \text { core staff } \\
\text { active at the } \\
\text { global level }\end{array}$ & $\begin{array}{l}\text { Distributing the survey to all GPEI } \\
\text { sub-groups } \\
\text { Gatekeepers from each } \\
\text { organization to either provide } \\
\text { contact information or distribute } \\
\text { the survey within global } \\
\text { organizations } \\
\text { GPEI listservs referring individuals } \\
\text { to a webpage with the survey }\end{array}$ & 1,400 & $\begin{array}{l}\text { Online survey } \\
(891 \\
\text { respondents) }\end{array}$ & 891 \\
\hline $\begin{array}{l}\text { Definitions } \\
\text { and Totals }\end{array}$ & $\begin{array}{l}\text { Across } 7 \text { countries and global staff } \\
\text { dedicated to polio eradication from } \\
1988 \text { to date, the estimated polio } \\
\text { universe: }\end{array}$ & $3,157,786$ & $\begin{array}{l}\text { Across } 7 \text { countries and the global } \\
\text { staff dedicated to polio eradication, } \\
\text { the number of individuals who } \\
\text { could be reached to take the survey: }\end{array}$ & 193,096 & $\begin{array}{l}\text { Number of } \\
\text { respondents } \\
\text { included in the } \\
\text { study } \\
\text { population }\end{array}$ & 3,955 \\
\hline
\end{tabular}

In Ethiopia, an at-risk country at the time of study design, the polio universe was estimated at 100,000 individuals by contacting key government agencies such as ministry of health, regional health bureaus, agencies, health professional associations, GPEI partners, civil society organizations, and international and local NGOs and obtaining estimates of their staffing levels. The most at-risk areas in the country, especially Somali, Gambella, and Benishangul Gumuz States, and southern Oromia State which borders Kenya were selected based on their highest risk for polio transmission and intense activities from the government and partners. Overall, a list of 150 key individuals at national, regional, zonal, district and health facility levels including frontline health workers was compiled with complete contact information for administering the survey.
In countries that had been free from wild poliovirus for over a decade, such as Bangladesh and Indonesia which last reported cases of wild polio in 2006, core actors were readily identifiable, however large population samples of actors were harder to identify. After attempting other sampling options, the Bangladesh team used a strategy of strict snowball sampling, starting from GPEI core partners and national health officials to identify 140 individuals across the country who were involved in polio eradication efforts and could be reached by survey efforts. Indonesia's disperse geography necessitated a different approach. Six provinces were selected, in consultation with the Ministry of Health, to conduct snowball sampling to obtain a sampling frame of subnational respondents. These provinces were based on areas of intense government activities where important lessons 
could be learned, such as the first province to switch to inactivated polio vaccine, the locations of the last wild poliovirus outbreak, and areas of conflict.

\section{Obtaining a comprehensive sample}

Data from the polio eradication-specific workforce was collected by administering a survey to a sample of the enumerated source population. Data collection involved a globally-distributed online survey and seven concurrent surveys implemented at the national and subnational levels by partner institutions in seven focus countries. The survey was administered to those identified in the source population, and those who answered comprise the study population. Respondents were provided with the opportunity to remain anonymous to ensure that they could voice their opinions without fear of repercussions. Several challenges prevented study teams from reaching the entire enumerated populations, including inaccurate contact information, individuals changing roles or leaving the country, and/or relatively low response rates. To address these challenges, teams utilized various methods of administering the same survey tool to ensure that responses were characteristic of the enumerated source populations both in terms of quantity of responses as well as a variety of respondents. The first method for reaching individuals was through an online survey which was sent directly to the emails of enumerated participants and made available in English and in eight languages commonly used in the partner countries. Challenges specific to this method included the fact that potential respondents may have missed the email, the email may have gone to 'spam' folders, or respondents may not have been aware of the purpose or legitimacy of the survey. Other methods, including inperson and mobile phone administration of the survey, supplemented these efforts and were useful in reaching enumerated respondents who were not reachable through online methods. Most countries utilized a combination of distribution techniques for administering the survey to a population that would represent a variety of organizational levels. The best method of reaching international, national, and some state-level actors was generally recognized to be an online survey (available in English and locally relevant languages), while in-person interviews were employed particularly to reach front-line immunizers. All methods utilized the same survey questionnaire (made available elsewhere in this series, see [18]), however questionnaires administered to field workers were translated into more accessible, locally appropriate terminologies.

Where countries had constrained their polio universe to a narrower source population that included a complete sampling frame, it is possible to evaluate the response rate $^{3}$ of the various survey distribution methodologies. In Ethiopia, the online survey platform had the smallest observed response rate, as only $6.8 \%$ of identified actors responded to the survey. Most countries experienced similarly low response rates to the online survey, however DRC's online survey had a relatively high response rate of $34.8 \%$ (Table 4). Close relationships between the study team and the government's vaccination program could account for such high levels of buy-in in DRC. All respondents who were administered the survey in-person consented and participated in the survey.

In areas where polio activities were ongoing, several strategies were effectively used to increase the study population. Nigeria was able to obtain a study population of 953 respondents by leveraging existing networks. The team utilized connections within the University of Ibadan College of Medicine to distribute the survey to former Master's students who had been involved in polio work, which, in concert with more available internet connection, contributed to the far reach of the survey. In contexts with conflict and less reliable internet connection, online surveys had lower response rates and inperson interviews were not feasible. Afghanistan increased its study population by administering the survey via mobile phone for respondents located in conflict areas. While Afghanistan was the only country to utilize this method, the response rate for the phone interview was nearly twice as high as the online survey (Table 4).

\section{Reflecting on the obtained sample}

It is important to reflect on the processes used and the samples obtained to provide insight on the strength of conclusions drawn during subsequent analysis. For the combined tacit knowledge survey, a total of 3.16 million individuals were estimated to exist in the polio universe, of which information was obtained for 193,096 individuals (about $6 \%$ of the universe). A total of 3,955 individuals were reached with the survey, equaling about $2 \%$ of the source population.

Recognizing that various challenges in countries (e.g. length of time since polio eradication in a geographic area, reaching conflict affected areas, reaching hard-toreach areas, and ensuring representation of front-line workers) required diversions from purely probabilitybased approaches, a number of strategies were adopted to obtain perspectives from relevant polio actors. For example, the sheer size of India's polio program complicated the estimation of a polio universe, resulting in a rough estimate of some 2.4 million individuals. In Bangladesh, actors involved in polio were harder to find due to the length of time since eradication, which

${ }^{3}$ Response rates are calculated as the number who responded to the survey / the number who were asked to respond to the survey. 
necessitated the use of snowball sampling. Conversely, the structured organization of DRC's polio universe allowed the team to confidently estimate the number of individuals in their polio universe and utilize systematic random sampling methods, increasing the likelihood that their study population is indeed representative of their polio universe. Variability in the process of operationalizing the polio universe, defining a source population, and data collection limits the strict generalizability of the findings of specific country surveys but yields important conclusions for the global polio eradication efforts more broadly. Across all surveys, efforts were made to specifically seek out and collect data from front-line workers, ensuring that those with first-hand experience were included across settings. The strategies and processes utilized in the tacit knowledge survey can be distilled into general steps for sampling from a complex initiative.

\section{Generalizing to other complex initiatives}

Based on the systematic approach used to obtain a sample for lessons learned in GPEI, the steps for obtaining a comprehensive sample for studying complex initiatives can be summarized as follows;

\footnotetext{
(i) State research goal(s)

(ii) Describe the program of interest

(iii) Define a sampling universe to meet these criteria

(iv) Estimate the size of the sampling universe

(v) Enumerate a source population within the universe that can be feasibly reached for sampling

(vi) Sample from your source population (collect data)

(vii) Reflect on the process to determine strength of inferences drawn
}

The STRIPE project demonstrated that the methodology described above can be effective in obtaining an extensive sample of participants in a complex global health initiative. The project first defined its goals to map and synthesize tacit knowledge, ideas, approaches, and experiences that are not documented but are relevant to understanding both intended and unintended results from polio eradication activities within various contexts. The second step was then to describe efforts that have and continue to contribute to the eradication of polio; including generalizable individual-level activities and goals, organizational and operational levels, and contexts/countries in which they operate.

In order to obtain the desired results, the STRIPE project collected responses from individuals associated with organizations involved with funding, researching, designing, managing, and/or implementing activities that contributed to polio eradication. A definition for a universe containing all units related to this objective was defined and adapted to better meet specific contexts. Two common approaches were to: (i) conservatively estimate the number of all individuals who could have possibly been involved using health-worker level estimates (Ethiopia and India) or (ii) estimate the workforce of key organizations identified (Bangladesh and Nigeria). Next, individuals within the universe were enumerated by a number of strategies, including primarily: (i) purposively or randomly selecting geographical sub-units within a country for enumeration (Afghanistan, DRC, Ethiopia, Indonesia, and Nigeria); (ii) utilizing snowball sampling when polio activities were further removed from time (Bangladesh) or to include perspectives of frontline workers (Indonesia, India, and Ethiopia); and (iii) convening stakeholders and enumerating as many individuals as possible within key organizations (India). Next, procedures were implemented to obtain a comprehensive sample of the enumerated population. Approaches utilized include: (i) snowball sampling of frontline workers within study areas (Bangladesh, Ethiopia, and Indonesia); (ii) random sampling within each identified study area (DRC); (iii) distributing to the census of the source population (India); and (iv) using existing networks to distribute the survey (Nigeria and Afghanistan). Finally, survey respondents and response rates can be compared with original estimates of the source population and universe to assess the comprehensiveness of the survey.

This sampling approach has several benefits that complement existing methods. Primarily, this systematic approach maps individuals involved in a complex initiative across operational levels and contexts, ensuring that perspectives are collected from actors who have a wide range of experiences. Such a methodology allows for the comparison of tacit knowledge both vertically (from frontline workers to strategic planners) and horizontally (across organizations and countries), enabling a holistic and comprehensive approach to synthesizing lessons learned. Such approaches are essential in complex initiatives and partnerships, which have historically focused on lessons learned from a limited number of perspectives, especially from policymakers and managers at global and national stages, leaving a gap in our understanding of lessons from the perspectives of sub-national and community level actors. This is the experience to date in the largescale evaluation of polio eradication activities. Since 2011, the Independent Monitoring Board (IMB) has been supporting the GPEI in its aims to interrupt polio transmission globally. Comprised of experts acting independently of GPEI, the IMB has published 17 reports on the status of polio eradication and recommendations to 
accelerate eradication as of November 2019 [23]. The IMB largely relies on data provided by GPEI organizations, as well as conversations with GPEI and government organizations, and short field visits [24, 25]. The STRIPE project collects much of the same data as the IMB; with reports and data provided by GPEI organizations captured in the series of literature reviews and conversations with policymakers captured in key informant interviews [18]. While the IMB has recommended the collection and review of field-level perspectives since its earliest days, there has yet to be a systematic collection of perspectives across the entire range of actors involved in polio eradication [25]. The main contribution of the tacit knowledge survey is to fill this gap in knowledge, and provide perspectives and experiences across a range of actors, organizational, and operational contexts that have not systematically been compared and synthesized to date.

This sampling approach will yield comprehensive data that will contribute new lessons learned to the polio eradication narrative, however there are some limitations that should be acknowledged. Operational obstacles prevented the survey from being implemented as planned, including the inability to obtain up to date and accurate contact information for potential respondents at all levels and inaccess to key operational areas, necessitating the adoption of multiple data collection approaches. Challenges also existed in the potential introduction of systematic error in data collection and entry across teams, as a variety of methods were used for data collection (e.g. self-report for global respondents, in-person collection by an enumerator via tablets, and separate data entry by data managers in some settings), however constant contact between study teams and a central, online platform for data collection helped to ensure standardization. Future attempts to derive lessons from complex global health initiative could be based on study populations that are defined in real-time, alongside the program implementation activities at various levels - which may not necessarily yield a consistent approach across settings but will be better aligned to the initiative.

As mentioned previously, differences in country team approaches result in varying levels of generalizability of findings from country-level surveys to holistic country polio eradication efforts. Some groups or countries may be overrepresented (e.g. Nigeria's relatively large study population) and others may be under-represented (e.g. Bangladesh or Ethiopia's relatively small study population), either as a result of gaps in theorizing the entire universe of actors involved, missing data when operationalizing their universe into a source population, or inability to reach individuals during data collection. However, in all contexts, key actors were readily found and included in the survey, and additional efforts were made to engage frontline workers, ensuring that the overall study population is indicative of experiences related to global polio eradication more broadly. Moreover, final conclusions about polio eradication under this study will not rely solely the data from the survey, but will be derived by combining data from multiple research streams (including literature reviews, key informant interviews, and health system analyses), contributing to the strength of these generalizations.

\section{Conclusion}

This paper provides a broad methodology for describing, enumerating and sampling from participants of a complex population and provides examples of methodological adaptations to best fit the application to distinct contexts. Solutions presented in this paper fill a gap in current operational, implementation, and health systems research, in that there are currently few methods for systematically sampling across complex public health initiatives that are implemented internationally by several organizations and stakeholders. By applying these methods, the STRIPE tacit knowledge survey was able to describe the universe of actors involved in GPEI, obtain information about these actors, and sample an impressive 3,955 individuals from the initiative. Such a systematic and extensive approach to collecting lessons learned from a global health initiative has not previously been undertaken. The insights obtained from the tacit knowledge surveys can be generalized to the overall polio eradication effort, as considerations were made at several levels to ensure rigor and comprehensiveness. Potential applications of the data collected in the STRIPE tacit knowledge survey can include investigations into country-specific barriers and facilitators of program success, analysis of common barriers and facilitators experienced over time, and a comparison of findings with IMB recommendations. Future research activities can draw from these methodologies to inform further systematic health systems research and increase the efficacy of public health initiatives by translating knowledge gained into improved programming that saves lives.

\section{Abbreviations \\ BMGF: Bill and Melinda Gates Foundation; CDC: United States Centers for Disease Control and Prevention; CSO: Civil Society Organization; DFID: Department for International Development; DRC: Democratic Republic of the Congo; EPI: Expanded Program on Immunization; GPEl: Global Polio Eradication Initiative; IMB: Independent Monitoring Board; NGO: Non- Government Organization; PEPFAR: US President's Emergency Plan for AIDS Relief; PMI: President's Malaria Initiative; STRIPE: Synthesis and Translation of Research and Innovations from Polio Eradication; UNICEF: United Nations Children's Fund; USAID: United States Agency for International Development; WHO: World Health Organization}

\section{Acknowledgements}

We would like to sincerely thank all team members of the STRIPE project for their guidance and support in the implementation of the survey and for their contributions to this manuscript. In addition to the authors of this manuscript, Professor S.D. Gupta and Drs. Piyusha Majumdar and D.K. Magnal 
of the IIHMR University in Japiur, India, Dr. Yodi Mahendradhata of the Gadjah Mada University in Indonesia, Dr. Wakgari Deressa of Addis Ababa University in Ethiopia, Dr. Oluwaseun Akinyemi of the University of Ibadan in Nigeria, Drs. Ahmad Shah Salehi and Ahmad Omid Rahimi of Global Innovation Consultancy Services in Afghanistan, Dr. Yameen Mazumder, and Humayra Binte Anwar of BRAC University in Bangladesh, and Professor Patrick Kayembe of the Kinshasa School of Public Health in DRC.

\section{About this supplement}

This article has been published as part of BMC Public Health, Volume 20, Supplement 2, 2020: Lessons Learned from Global Polio Eradication. The full contents of the supplement are available at https://bmcpublichealth. biomedcentral.com/articles/supplements/volume-20-supplement-2.

\section{Authors' contributions}

MAP wrote the survey protocol and the first draft of the manuscript. OA conceived the study, is the principal investigator for the STRIPE project, wrote the STRIPE proposal and protocol, and provided critical revisions to the drafts of the manuscript. Each author contributed experiences from conducting the survey in their own country (WD for Ethiopia, MS for Bangladesh, NS for India, EO for Nigeria, RA for Indonesia, TS for Afghanistan, EM for DRC) and contributed to revisions of the manuscript. All reviewed and approved the final manuscript.

\section{Funding}

Funding from the STRIPE project is provided by the Bill and Melinda Gates Foundation

\section{Availability of data and materials}

The datasets used generated from the current study are available from the corresponding author on reasonable request and will be made available at the STRIPE repository upon project completion.

\section{Ethics approval and consent to participate}

Not applicable

\section{Consent for publication}

Not applicable

\section{Competing interests}

The authors declare that they have no competing interests

\section{Author details}

'Johns Hopkins University Bloomberg School of Public Health, Baltimore, MD, USA. ${ }^{2}$ Addis Ababa University School of Public Health, Addis Ababa, Ethiopia. ${ }^{3}$ BRAC University JP Grant School of Public Health, Dhaka, Bangladesh.

${ }^{4}$ Indian Institute of Health Management Research, Jaipur, India. ${ }^{5}$ University of Ibadan College of Medicine, Ibadan, Nigeria. ${ }^{6}$ Gadjah Mada University Faculty of Medicine, Yogyakarta, Indonesia. ' Global Innovations Consultancy Services, Kabul, Afghanistan. ${ }^{8}$ University of Kinshasa School of Public Health, Kinshasa, Democratic Republic of the Congo.

Received: 23 March 2020 Accepted: 25 March 2020

Published: 12 August 2020

\section{References}

1. Institute of Medicine. Evaluation Design for Complex Global Initiatives [internet]. Washington, D.C.: National Academies Press; 2014. [cited 2019 May 24]. Available from: http://www.nap.edu/catalog/18739.

2. Craig P, Dieppe P, Macintyre S, Mitchie S, Nazareth I, Petticrew M. Developing and evaluating complex interventions: the new Medical Research Council guidance. BMJ. 2008:337:979-83.

3. World Health Organization Maximizing Positive Synergies Collaborative Group, Samb B, Evans T, Dybul M, Atun R, Moatti J-P, et al. An assessment of interactions between global health initiatives and country health systems. Lancet (London, England). 2009;373(9681):2137-69 [cited 2019 May 24]. Available from: http://www.ncbi.nlm.nih.gov/pubmed/19541040

4. Porta M. A dictionary of epidemiology. 6th ed: Oxford University Press; 2014. https://www.oxfordreference.com/view/10.1093/acref/9780195314496.001. 0001/acref-9780195314496.
5. Duintjer Tebbens RJ, Pallansch MA, Cochi SL, Wassilak SGF, Linkins J, Sutter RW, et al. Economic analysis of the global polio eradication initiative. Vaccine. 2010;29(2):334-43 [cited 2019 May 24]. https://doi.org/10.1016/j. vaccine.2010.10.026

6. Lavrakas PJ. Encyclopedia of survey research methods: SAGE Publications; 2008. [cited 2019 May 24]. Available from: https://us.sagepub.com/en-us/ nam/encyclopedia-of-survey-research-methods/book227714.

7. Drabek TE, Braito R, Cook CC, Powell JR, Rogers D. Selecting samples of organizations: central issues and emergent trends. Sociol Perspect. 1982; 25(3):377-400

8. Kalleberg AL, Marsden PV, Aldrich HE, Cassell JW. Comparing organizational sampling frames. Adm Sci Q. 1990;35(4):658 [cited 2020 Jan 3];Available from: https://www.jstor.org/stable/2393513?.origin=crossref.

9. Kendall C, Kerr LRFS, Gondim RC, Werneck GL, Macena RHM, Pontes MK, et al. An empirical comparison of respondent-driven sampling, time location sampling, and snowball sampling for behavioral surveillance in men who have sex with men, Fortaleza, Brazil. AIDS Behav. 2008;12(S1):97104 [cited 2019 May 24]. Available from: http://link.springer.com/10.1007/s1 0461-008-9390-4.

10. Topp $L$, Barker $B$, Degenhardt $L$. The external validity of results derived from ecstasy users recruited using purposive sampling strategies. Drug Alcohol Depend. 2004;73(1):33-40.

11. Reichel D, Morales L. Surveying immigrants without sampling frames evaluating the success of alternative field methods. Comp Migr Stud. 2017; 5(1):1 [cited 2019 May 24]. Available from: http://

comparativemigrationstudies.springeropen.com/articles/10.1186/s40878-0160044-9.

12. Egan M, McGill E, Penney T, Meier PS, Savona N, de Vocht F, et al. Complex systems for evaluation of public health interventions: a critical review. Lancet. 2018;392:S31 [cited 2020 Jan 9]// Available from: https://www. sciencedirect.com/science/article/pii/S0140673618320531?dgcid=api_sd_ search-api-endpoint.

13. UNAID. External evaluation of the President's malaria initiative - final report executive summary; 2011.

14. Ryan L, Sarriot E, Bachrach P, Dude B, Cantor D, Rockwood J, et al. Evaluation of the organizational effectiveness and efficiency of the Global Fund to fight AIDS, tuberculosis, and malaria results from study area 1 of the five-year evaluation. Evaluation. 2007; [cited 2019 May 24]; Available from: https://www.theglobalfund.org/media/2984/terg_sa1_report_en. pdf?u=637066527980000000

15. Mookherji S, Ryan L, Ricca J, Bize M, Dye T. Evidence of the Global Fund partner environment at global and country levels in relation to grant performance and health system effects; 2008. p. 1-311. Available from: papers2://publication/uuid/8F94F7DE-7B18-449B-8A13-A261F8AA3162.

16. Institute of Medicine. Evaluation of PEPFAR. Washington, D.C.: National Academies Press; 2013. [cited 2019 May 24]. Available from: http://www.nap. edu/catalog/18256.

17. Hulls D, Wrobel S, CEPA LLP, Applied Strategies. GAVI second evaluation report; 2010;(September); [cited 2019 May 24]; Available from: https://www. gavi.org/results/evaluations/gavi-second-evaluation-report/.

18. Alonge O, Neel A, Kalbarcyk A, Peters MA, Mahendradhata Y, Sarker M, et al. Synthesis and translation of research and innovations from polio eradication (STRIPE): initial findings from a global mixed methods study. BMC Public Health. 2020. https://doi.org/10.1186/s12889-020-09156-9.

19. Peters DH, Tran NT, Adam T. Implementation research in health: a practical guide; 2013

20. Leeman J, Birken SA, Powell BJ, Rohweder C, Shea CM. Beyond "implementation strategies": classifying the full range of strategies used in implementation science and practice. Implement Sci. 2017;12(1):125 [cited 2020 Jan 9]. Available from: http://implementationscience.biomedcentral. com/articles/10.1186/s13012-017-0657-x.

21. Powell BJ, Waltz TJ, Chinman MJ, Damschroder LJ, Smith JL, Matthieu MM, et al. A refined compilation of implementation strategies: results from the expert recommendations for implementing change (ERIC) project. Implement Sci. 2015;10(1):21 [cited 2020 Jan 9]. Available from: http://implementationscience.biomedcentral.com/articles/10.1186/s13012015-0209-1

22. WHO. Strengthening health systems to improve health outcomes: WHO's framework for action; 2007.

23. Independent Monitoring Board of the Global Polio Eradication Initiative. The art of survival: the polio virus continues to exploit human frailties; 2019. 
24. Independent Monitoring Board of the Global Polio Eradication Initiative. Now is the time for peak performance; 2015.

25. Independent Monitoring Board of the Global Polio Eradication Initiative. Independent monitoring Board of the Global Polio Eradication Initiative Report April 2011; 2011. p. 1-24.

\section{Publisher's Note}

Springer Nature remains neutral with regard to jurisdictional claims in published maps and institutional affiliations.

Ready to submit your research? Choose BMC and benefit from:

- fast, convenient online submission

- thorough peer review by experienced researchers in your field

- rapid publication on acceptance

- support for research data, including large and complex data types

- gold Open Access which fosters wider collaboration and increased citations

- maximum visibility for your research: over $100 \mathrm{M}$ website views per year

At $\mathrm{BMC}$, research is always in progress.

Learn more biomedcentral.com/submissions 